\title{
Two Visions of Greatness: Roleplay and Realpolitik in UK Strategic Posture
}

\author{
David Blagden ${ }^{1}$ \\ Strategy and Security Institute, Department of Politics \\ University of Exeter \\ d.w.blagden@exeter.ac.uk
}

This is an open-access draft of an article accepted for publication in

Foreign Policy Analysis:

It represents the version that the journal accepted for publication, but has not undergone copyediting, production, or post-acceptance updates

Accepted: 5 May 2018

\begin{abstract}
How do states' desires to perform an international-societal role interact with the imperative to safeguard their security in an anarchic international system? Using the case of the contemporary United Kingdom, this article explores the tensions between roleplay and realpolitik - gaining social recognition as a particular kind of state while doing what it takes to survive - through one key role conception, "Great Power". Recent scholarship has dubbed Britain a "residual Great Power": lacking the wherewithal to impose regional order through preponderance, it is still cast into the role of militarized international order-upholder by the allies whose support is necessary for such rolesustainment, America and France. Yet this role-based approach sets a different threshold on capability than the requirement to undertake survival-essential military missions, independent of potentially unreliable allies' charity realists' understanding of "great power". Theoretically, therefore, the article demonstrates that roleplay and realpolitik remain separate incentive structures underlying states' foreign policy choices. Empirically, meanwhile, the article shows - through opportunity-cost force-posture analysis - that contemporary Britain is torn between the logics. Striving for independent self-protection capabilities, above-and-beyond the "residual power" criterion, London nonetheless makes a residual power's implicit assumptions about alliance support in the deployment of those capabilities.
\end{abstract}

\footnotetext{
${ }^{1}$ Author's Note: I thank Stephane Baele, Joslyn Barnhart Trager, Gregorio Bettiza, Richard Foord, Andrej Krickovic, Patrick Porter, Carsten Schulz, Henning Tamm, Catarina Thomson, Kit Waterman, participants in the 2017 Annual Convention of the International Studies Association, participants in the University of Exeter's Centre for Advanced International Studies seminar series, the anonymous reviewers, and especially Helena Mills for invaluable comments on versions of this article.
} 
Nothing animates British foreign and defense policy elites like obsessing over their country's "role" in the world, and the gnawing subtext, whether Britain is still "Great." Dean Acheson's oft-invoked 1962 barb to U.S. Military Academy cadets that "Great Britain has lost an empire and not yet found a role" - front-page news in an outraged London (Brinkley 1990:601) touched a nerve. The post-Cold War "unipolar moment" of U.S.-led Western dominance (Krauthammer 1990-91; Wohlforth 1999), with its "end-of-history" optimism and scope for UK leadership of humanitarian foreign-policy initiatives (Cook 1997; Blair 1999), provided a brief respite from the hand-wringing. But post-2001 embroilment in Washington's flawed "Global War on Terror" alongside fiscal overstretch since the 2008-9 financial crisis has returned rolethemed soul-searching to Britain's strategy-making community. The just-elected ConservativeLiberal coalition government's 2010 National Security Strategy and accompanying Strategic Defence and Security Review (NSS/SDSR) - the official effort at squaring expansive global commitments with newly-straitened circumstances - began by asserting that national strategy must consider what "role" Britain wants to "play" in the world (HM Government $\left.{ }^{2} 2010 \mathrm{a}: 4\right)$. Policymakers and pundits invoke an allegedly "special" UK world role as a rationale for foreignpolicy decisions, ${ }^{3}$ while scholars utilize role-based analyses of Britain's international position and strategic choices. ${ }^{4}$ With Britain's exit from the European Union ("Brexit") looming, British role concerns have also contributed to a major recent international-systemic shock (Blagden 2017:8-9) and will be prominent in public debate for the foreseeable future (Landale 2016; Nougayrède 2016). Indeed, Prime Minister Theresa May has felt compelled to explicitly reassert Britain's "confident role" as a "global power" as Brexit unfolds (Giles and Martin 2017; The Telegraph 2017).

\footnotetext{
2 "HMG" hereafter.

${ }^{3}$ See, for example: The Guardian (2010), Niblett (2010), Clarke (2010), Stevenson (2011), Jenkin and Grant (2011), Porter (2013), Dominiczak (2013), New Statesman (2015), Robbins (2015), The Economist (2015), David (2015), Norton-Taylor (2015b), Fry (2015), Singham (2016), Blair (2016), Financial Times (2016).

${ }^{4}$ This theme endures throughout research on post-1945 UK foreign/defense policy. See: Waltz (1967:241), Shlaim (1975), Hill (1979; 2016), Barber (1980), Breuning (1995), MacLeod (1997), Porter (2010:10), Turner (2010), McCourt (2011a; 2011b; 2014a; 2014b), Morris (2011), Gaskarth (2014).
} 
Britain's obsession with world role presents a puzzle, however. In realist international thought, states do not have societal "roles"; they simply have a hierarchy of interests - survival, security, independence, prosperity, and so forth - plus varying levels of power to pursue such interests (Morgenthau 1973:5-8). ${ }^{5}$ Certainly, most states have role concerns (Holsti 1970) - the likes of Germany, Turkey, Brazil, and even China and the United States are all currently debating their "place" in world affairs (Gürzel 2014; Hicks 2015; Neves and Collins 2015; Steinmeier 2016; Jones 2017). Nonetheless, Britain's role-obsession seems symptomatic of particular circumstances: status anxiety, an elite/public self-conception characterized by international activism, a certain relationship to major allies, and substantial-yet-not-preeminent national capabilities. Britain is thus an alliance-sustained "residual Great Power", according to David McCourt (2014a:2), hence its fixation on role-performance.

This article advances two related arguments - one UK-specific, the other theoretically generalizable. First, despite its obsession with role-performance, Britain still seeks to be more than a mere alliance-reliant "residual" great power - and succeeds, to some extent. Instead, the UK still strives to be a "real" major power, too: to possess sufficient military capability in certain perceivedly crucial domains to be capable of safeguarding its own survival against all potential adversaries, independent of alliance support; a behavior motivated by the self-help characteristics of an anarchic international system. Yet even while consciously bearing significant opportunity costs to hedge against alliance abandonment, Britain also makes habitual assumptions (Hopf 2010) about the stability of U.S.-dominated international order and its role within it, consistent with the "residual power" thesis. In short, British strategic posture is shaped by the interaction between two conflicted understandings of purpose. Second, moving to theoretical generalization, Britain's confliction illustrates that roleplay and realpolitik must be understood as distinct incentive structures motivating states - incentives that can align, but often do not - rather than

\footnotetext{
${ }^{5}$ This over-simplification is unpacked subsequently.
} 
being amenable to neat elision. That, in turn, implies boundaries on the explanatory power of foreign-policy role theory, as discussed below.

Assessing competing understandings of national "greatness" reveals much about what states value, thereby illuminating variables that matter in International Relations (IR). Role is social, relational, and performative - it is about deriving utility from being seen as the sort of actor that discharges certain rights and responsibilities. If performing a certain role is the highest of state interests, therefore, it could conflict with other interests: states can benefit from military restraint, say, yet restraint may be anathema to a country that defines itself by international activism. Role-based understandings of national standing focus on whether a state is seen to behave in the way that "Great Powers" - a proper noun, defined by discharging sets of societal expectations - do. Realist understandings of "great power", by contrast - used as a mere description of capability - focus on whether a state can safeguard its vital interests independent of others' charity, even against comparably-capable states.

Britain displays the tensions between these two conceptions of greatness clearly, providing a test-bed for several questions in IR and Foreign Policy Analysis (FPA). ${ }^{6}$ Is status manifested in the UK as pursuit of great-power recognition via role-performance - simply one, potentially subordinate concern among states' hierarchy of interests? ${ }^{7}$ Or does role constitute interests, a more ambitious causal claim? How does a general concern with Great Power status interact - and potentially conflict - with other, more specific materially-based interests: the ability to deter particular adversaries, say, or hold vulnerable territory? And how do concerns from each "category" - roleplay versus realpolitik - interact in the making of national security policy?

The article first outlines the role-based understanding of "Great Power" that is integral to understanding UK foreign/defense policy. Second, it discusses the realist critique of role-based

\footnotetext{
${ }^{6}$ Contending that role-analysis can connect IR/FPA, see Thies and Breuning (2012:2-3).

${ }^{7}$ For status as state-behavioral motivator, see: Paul, Larson, and Wohlforth (2014); Volgy et al. (2011); Lebow (2010); Larson and Shevchenko (2010).
} 
understandings. Third, the article explores the theoretical tensions between role-based and realist conceptions of national "greatness". The article then examines UK posture across three key areas of military capability - the nuclear arsenal, naval fleet composition, and defensive air power between NSS/SDSR 2010 and the present. Across each, an ongoing tension emerges between role-performance and realpolitik: between simply possessing sufficient capability to act in support of U.S.-led international order as the sort of state that does so, versus retaining enough capability to independently conduct survival-essential military missions. ${ }^{8}$

The article yields conclusions valuable to both scholarship and policy. Where UK strategic choices are driven by international-societal role-performance concerns, this provides evidence of a state making costly trade-offs in pursuit of a particular social identity. Yet where the desire to retain independent capability remains, the realist concern to safeguard one's own security under international-systemic anarchy still influences contemporary British strategy. This interplay of social and material forces contributes to both constructivist and realist research programs, and their intersection: neoclassical realism, with its focus on the filtration of international-systemic pressures through domestic-political lenses (Kitchen 2010). The article is not an advancement of the rich threads within role theory (Thies 2017), although it discusses their application to Britain. Rather, it explores the interaction between one prominent international-societal role, "Great Power," and alternative, materially-defined renderings of the same concept. It defends the analytical value of pitting role-based and realist conceptions of "greatness" against each other, as distinct incentive structures, rather than seeing material wherewithal to defend state survival as simply part of national role. This further specifies role theory, by identifying one of its explanatory boundaries: the point at which social role-

\footnotetext{
${ }^{8}$ As Stacie Goddard and Daniel Nexon observe (2016), realpolitik and realism are not identical - realpolitik, as a tradition of practical foreign-policy thought, does not "belong" to any one school of IR theory. That said, realpolitik is here treated as the foreign/defense policy prescriptions that follow (non-exclusively) from certain realist assumptions about world politics (see Bew (2015:5-7,13-14) for discussion). This appreciates the original nineteenth-century meaning - pursuit of progressive domestic-political goals in the face of a regressive international-political system - while also recognizing the broader connotations that the term has taken on (Bew 2015:8-12).
} 
performance gives way to structurally-motivated national security requirements. Such dichotomization is not intended to deny the obvious: that both ideational and material power matter in real-world foreign/security policy. But isolating roleplay versus realpolitik as heuristic ideal-types enables us to better understand how the real-world spectrum between the ideational and material operates, ${ }^{9}$ with different logics of international-political behavior - consequences, appropriateness, habit (Hopf 2010:539) - exerting different weight at different times, and often pulling state policy in different directions.

Understanding UK strategic posture, meanwhile, matters in its own right: Britain remains the second-most-capable military power in NATO on many understandings, and the secondmost-capable globally on some. Given a newly capricious U.S. administration, anyone interested in the Western alliance's ability to defend itself should care about UK strategy. The British relationship to the American superpower, in particular, emerges as paradoxically torn between dependency-enabled roleplay and genuine self-sufficiency. Where London still strives for costly independent capability, beyond baseline requirements of "residual power" role-performance sufficient ballistic missile submarines and aircraft carriers to deliver permanent operational availability, rather than the mere symbolism (and cost savings) of $a$ carrier or some nuclear weapons - the rationale remains self-reliance. And yet many assumptions underpinning the use of these capabilities rest on the habit of operating within a U.S.-dominated international order, which has supplied unrivaled Western "command of the commons" - sea, air, space - since 1990 (Posen 2003).

Britain's greatness concerns also shed light on the behavior of similarly status-obsessed second-tier powers, like Russia and France. Yet the relative absence of such concerns from other comparably-sized/-developed economies, such as Germany, Japan, and Italy - which define their role more by peaceful rule-compliance than militarized order-enforcement (Maull 1990) suggests that "greatness anxiety" owes to more than mere relative material standing. Examining

\footnotetext{
${ }^{9}$ On explanatory-IR-as-utilitarian-heuristic, see Humphreys (2011).
} 
states with Britain's combination of sizeable international ambition and relatively modest material means also provides more clarity over competing conceptions of "greatness" than focusing on countries - such as the United States or China - that perform a "great" internationalsocietal role and possess vast material resources. The point is not to find a "correct" definition of great power - either may be more appropriate, depending on the question at hand (Sil and Katzenstein 2010). Role, status, and other social variables may be essential to understanding the motivations behind states' behavior. ${ }^{10}$ At the same time, relative material capabilities may provide the most appropriate understanding of international structure under anarchy, while providing crucial recommendations for prudent, security-maximizing policy. That said, the analysis suggests that there may be two different spectrums of "greatness" - one characterized by internationally active role-fulfilment, the other by relative material power - which are related (a state with no power cannot discharge an international role, while a state with vast power cannot avoid some international role), but not identical.

\section{The Social Construction of a Great Power "Role"}

That norms, identities, culture, and roles can shape states' interests and preferences is well established in IR, both in general and in Britain's specific foreign-policy context. ${ }^{11}$ A role "is the set of expectations attached to the behaviour of an actor in a given social situation, like 'father' or "customer"' (McCourt 2014b:160) [emphasis added]. As a theater metaphor, role denotes the "parts" played, rather than the unique "players" who recite them - making it a more specific concept than "identity" - thereby implying the behaviors anticipated by others' expectations of players' appropriate conduct (Thies 2017). Role is related to - but subtly different from - status; the latter is concerned with relative standing and recognition, the former with performance. That

\footnotetext{
${ }^{10}$ Even committed structural realists concede that variables other than relative power are necessary to explain individual foreign-policy choices (Waltz 1993; Mearsheimer 2009).

${ }^{11}$ On the former, see Klotz (1995) and Hopf (1998:174-77). On the latter, see Breuning (1995), Gaskarth (2006, 2014), McCourt (2011a, 2011b, 2014a, 2014b), Morris (2011), Crowcroft and Hartley (2012), Gilmore (2014), and Humphreys (2015).
} 
said, for states seeking to perform a great power role, the two are mutually reinforcing. Thinking of a state's strategic position as playing a role means that such a role must, necessarily, be a social construction. ${ }^{12}$ Using this approach, therefore, a state is a great power if other states recognize it as one, in terms of the international-social role they expect it to perform. ${ }^{13}$

"Role" is neither fixed nor singular (Thies 2017). States can play multiple roles (Holsti 1970:277), with certain ones becoming salient at certain times, due to exogenous circumstances and/or intentional mobilization for political effect. Multiple roles often co-exist smoothly, but sometimes generate "inter-role conflict" - "regional order-upholder" versus "active independent" was a key fault-line in the Brexit vote, for example (Blagden 2017:8-9). More powerful states can choose more roles and disregard inconvenient ones, suggesting a relationship between material wherewithal and social standing. Some roles are ascribed: states occupy them at others' behest. Others are achieved: states choose when to switch them on/off. Role can also operate across different levels of analysis, accounting for individual foreign-policymakers' preferences, state-level identities, or international-systemic outcomes - and interacts across all three. The applicability to Britain is evident: role features as first-image ideational prism for policymakers and thought-leaders (see footnote 2), as second-image driver of state-level behavior, and as thirdimage explanation of the UK's still-elevated place in international order.

Different elements of a state may also conceive of its role differently, as may overseas audiences, producing fluidity and contestation (Cantir and Kaarbo 2012; Brummer and Thies 2014). Voters may applaud the country performing an elevated international-political role, but disagree - among themselves and/or vis-à-vis elites - over what that role should be. ${ }^{14}$ Different bureaucratic departments - defense versus overseas development, say - could disagree about

\footnotetext{
${ }^{12}$ For the origins of foreign-policy role theory, see Holsti (1970) and Walker (1987). For a contemporary overview, see Thies (2017). For its importation into constructivism via the suggestion that certain roles -

"friend"/"rival"/“enemy" - modify interstate relations under anarchy, see Wendt (1999:313-69). For linkage of rolebased FPA to constructivist IR, see Thies and Breuning (2012) and McCourt (2014a:1).

${ }^{13}$ On international-social practice as state-behavioral determinant, see Hopf (1998:177-80). On the value states attach to safeguarding/affirming identity, see Mitzen (2006).

${ }^{14}$ Consider contestation over UK military-interventionism (Helm 2013) or Brexit (Blagden 2017:8-9).
} 
their state's role and its discharge (Crowcroft and Hartley 2012; Jones 2017). Contemporary Britain displays all such traits - yet the shared idea of a major international role continues to animate British policy elites, with qualified public support. ${ }^{15}$

The special role for "Great Powers" as an exceptional category with the wherewithal - as military powers of the "first rank" - and the responsibility to use force to uphold international “order” was advocated by Hedley Bull (1977:201), following Kalevi Holsti’s (1970:283) identification of powerful states' superior role-performance potential. The realist theory Bull critiqued sees greatness solely in terms of relative capabilities, under which the UK has clearly not qualified as a systemic "pole" since 1945 (Waltz 1979:162; Monteiro 2014:3) ${ }^{16}$ - although unlike both Bull and Waltz, certain contemporary realists identify a category of analyticallydistinct, structurally-defined second-tier major powers that includes Britain. ${ }^{17}$ Constructivist particularly English School - approaches to international theory, by contrast, have developed Bull's argument, suggesting that even under anarchy, role-based understandings of interstate hierarchy, legitimate behavior, and intersubjective recognition can all shape international behavior (Clark 1989, 2005, 2009; Lake 1996, 2011; Hopf 1998:174; Hurd 1999). A state must certainly possess substantial military wherewithal to qualify as a great power under such approaches. Yet while possession of capability is necessary, it is not sufficient, since fulfilling the "Great Power" role requires discharge of certain societal responsibilities to uphold international order. Bull (1977:202) thus concludes that neither Napoleonic France nor Nazi

\footnotetext{
${ }^{15}$ Even following Parliament's 2013 Syrian non-intervention vote, $75 \%$ of Britons still thought the UK should play a major world role to promote its economic interests, while $65 \%$ thought likewise to promote national security (YouGov 2013:7-8).

${ }^{16}$ At most, U.S. structural realists have seen post-Cold War Britain as a potential great power, with underlying economic potential to generate great-power capabilities if pressed (Mearsheimer 2001:392). Taking the view that only poles - states capable of independently balancing the other most powerful state(s) in the system - are true great powers leads to the conclusion that Britain obviously is not one, although this begs the question of whether "great" and "major" power are distinct categories.

${ }^{17}$ Nuno Monteiro's contention (2014:43-45) that a handful of states (China, India, Russia, France, and Britain) possess sufficient capability to avoid certain defeat by any other state suggests that there is indeed an analytically distinct, structurally-identifiable major-power category, even under unipolarity.
} 
Germany qualified as Great Powers, despite their military might, since they sought to destroy not support - the prevailing international order.

Building on such approaches, Justin Morris (2011) suggests that contemporary Britain retains a plausible claim to a Great Power role because it acts militarily to uphold international order on a scale greater-than-or-equal-to all bar the United States, plus its policy elites continue to think in these terms. McCourt qualifies this, labelling Britain a "residual Great Power" (2014b:160). It uses military force abroad - along with diplomatic trappings of greatness, such as veto-wielding permanent membership of the UN Security Council - in defense of its conception of international order; hence the "Great Power" role. UK foreign-policy elites are also cognitively and discursively bound by this self-conception (McCourt 2011:145-64). This role is "residual", however - a legacy of historical power position plus habit (Hopf 2010) - and relational because it is enabled by close alliance with the United States, and because similarlyresidual France attempts the same, allowing burden-sharing. On this reading, the UK already lacks the "full-spectrum" military capability to independently exercise regional preponderance (part of Bull's conception). Such relative weakness would not be terminal to Britain's fulfilment of role-defined "greatness," however, because alliances are also part of that role and provide the necessary support to order-upholding military activism (McCourt 2014b:160). ${ }^{18}$ "Great powerness" is thus ascribed by others, including two capitals crucial to its continuing enactment (Washington and Paris), enabling inter-behavioral role-sustainment (Thies 2017). Jamie Gaskarth argues (2014:565,579-80), meanwhile, that Britain has abandoned the "Great Power" role through material necessity - partially contra Morris/McCourt - but still contends that the UK occupies an elevated international-societal position. And Christopher Hill (2016:394-95) similarly identifies that post-1945 Britain - like France - has sought to act as a power less than "super" but more than "middling", even in their straitened twenty-first-century circumstances.

\footnotetext{
${ }^{18}$ For McCourt (2014a:26), role is not an identity that states "choose" to "play", but something states take on, when cast into it by others (see also Thies 2017).
} 
Such conclusions, if accepted, carry implications for force posture. On this view, loss of capability may indeed preclude independent military tasks, but Britain would not intend to accomplish such tasks independently anyway (McCourt 2014b). Rather, the point is to continue to play the role of the sort of country that uses force to support Western-defined international order, alongside France and subordinated to the United States. ${ }^{19}$ Such social role is unlikely to be lost suddenly, provided that some capability is preserved for performative purposes. Tropes like "punching above our weight", "Special Relationship", "Atlantic bridge”, "force for good”, and "Anglosphere" would not then be the substance-free rhetorical obstacles to effective national strategy that critics charge (Strachan 2009; Porter 2010). Rather, they would define Britain's role and thereby constitute UK strategic interests (McCourt 2014a, 2014b).

\section{Is Greatness Socially Constructed? Military Power and the Hierarchy of State Interests}

Two realist premises - that states seek to survive and that military power is their only reliable guarantee of doing so, given uncertainty over others' intentions under anarchy - elucidate the tension in role-based conceptions of states' "greatness" (Copeland 2000, 2003; Mearsheimer 2001:31-36). McCourt, for example, asserts that states' roles are not the same as their interests, ambitions, values, or capabilities (2014b:166), recognizing that states can have interests beyond playing a particular role. Yet he also asserts (2014b:174) that Britain's international-social role produces national interests, implying that interests all derive from role-identity; a more ambitious social-constructivist claim.

This ambiguity enables certain role theorists to jump from role mattering, uncontroversially, as an interest of states to it being the paramount interest - a necessary leap if arguing that great powers are constituted and defined by playing the social role of Great Power. The less contentious point - that playing any international-societal role is one of multiple interests - suggests that role may remain subordinate in a hierarchy of concerns, whereby the 
most fundamental interest remains political survival as a sovereign entity: states that do not survive cannot achieve anything else, either (Waltz 1979:91-92; Mearsheimer 2001:31). ${ }^{20}$ Following a "hierarchy of needs" approach (Maslow 1943), the corollaries to this survival assumption may include human/biological security for the state's population and preserving some welfare-essential level of economic prosperity. And crucially, realists contend, these hierarchy-topping interests all have a material base, physically independent of social roleconstruction. That is not to deny that capabilities, conurbations, economies, and indeed states are social constructions, nor that threats to societies are socially/culturally construed (Price and Tannenwald 1996; Hopf 1998:177-80). ${ }^{21}$ Nonetheless, the material effects of kinetic energy on human bodies, delivered via bullets or bombs, place these possibilities - and their avoidance top of states' spectrum of concerns (Thayer 2000).

Accepting this hierarchy of interests, alongside realism's identification of the inherent dangers of an anarchical international system, incentivizes the possession of sufficient capability to conduct certain military missions to secure the state and its population. ${ }^{22}$ These may include deterring/repelling the conquest of sovereign territory (necessary for political/biological survival), deterring/resisting coercion against the state's population (ditto), safeguarding sea lines of communication (necessary for baseline prosperity in a trade-dependent island), deterring major power aggression in the state's own region (lest an adversary accrue enough power to threaten political/biological survival), and so forth. Consequently, the principal underpinning of "great powerness" - military capability, with its deterrent/coercive/compulsive effects (Art 1980) - is a means to an end (security), rather than an end in itself (status). ${ }^{23}$ And providing for one's own survival through independent military wherewithal - rather than trusting wholly to allies -

\footnotetext{
${ }^{20}$ For a UK application, see Blagden (2009:63).

${ }^{21}$ Of course, states are socio-political constructions to which citizens form ideological attachments (nationalism), albeit driven by the physical-biological survival needs of human beings (Tilly 1992). Ultimately, resolving the intractable "material-versus-ideational" dispute lies beyond the scope and needs of this paper.

${ }^{22}$ On the relationship between achievement of national objectives and possession of sufficient capability to accomplish associated military missions, see Glaser (2010:40-41).

${ }^{23}$ Publics may still derive utility from "great" status, but military power's main purpose is to safeguard future security/prosperity (Fearon 2011:436-37).
} 
may require superior national capabilities compared to merely discharging a societal role alongside allies.

Of course, states other than superpowers also both want to survive and succeed in doing so. Intelligent alignment with powerful allies, accommodating others' preferences, and avoiding confrontation with powerful adversaries are all elements of effective, security-maximizing national strategy (Geyer 1986). Over-armament can also be self-defeating, when it provokes counterbalancing (Walt 1985). Part of Britain's post-1945 success has been effective strategy of this kind. Bandwagoning with U.S. strategy to incentivize Washington to serve as NATO's principal security guarantor, in particular, has enabled prioritization of UK public services (e.g. free-to-access healthcare) over higher defense spending. Britain's relatively modest internal balancing has thereby been offset by another's comprehensive external balancing commitment, allowing a favorable "guns/butter" trade-off - although such bandwagoning is not cost-free, as Britain's commitment to 2003's American-led Iraq invasion demonstrated (Dunne 2004). Britain's U.S./French alliances are not, therefore, unambiguous evidence of weakness; they also demonstrate calculated statecraft. ${ }^{24}$ Survival is multiply realizable through strategies informed by relative power plus information on others' capabilities and motives (Glaser 2010), ${ }^{25}$ with close alliance-dependence - even at the expense of autonomy - readily explicable through realpolitik.

Nonetheless, wholesale dependence on external balancing carries risks: of abandonment/coercion by the patron, and of chain-ganging into allies' wars, among others. There are thus good reasons - on a realist reading - to desire independent military-security capability (Mearsheimer 2001:156-57). Such incentives therefore motivate states with the requisite economic wherewithal - among which Britain barely still qualifies, hence the tension to favor retaining the baseline military capability suite necessary to discharge survival-essential military missions over merely focusing on role-performance.

\footnotetext{
${ }^{24}$ Likewise for many European countries, of course (Wivel 2008).

${ }^{25}$ Friend/enemy identities may condition motives (Wendt 1999), although realists question such relationships' reliability.
} 
Fundamentally, this argument is not about "greatness" or its absence. There are roles other than "Great Power", and states other than great powers want to survive. It is an argument, rather, about what constitutes state interests: performing an international-societal role, or safeguarding a hierarchy of materially-underpinned concerns topped by continued existence. It just so happens that, in the contemporary UK case, this tension between roleplay and realpolitik manifests as an anguished public debate about continuing national "purpose", enabling onlookers to observe the interplay.

\section{Can Roleplay and Realpolitik Coexist? The Theoretical Tension}

This article accepts that UK foreign/defense policy discourse is heavily influenced by role conceptions. Yet if role is not - as realists retort - the sole source of all state interests, but merely one interest among several, how far can roleplay and realpolitik coexist in a state's strategic posture? This section examines whether these two different conceptions of state interest can coexist from a theoretical perspective, again through the prism of competing understandings of national "greatness".

English School variants of social IR theory always maintained that to be a great power, a state must be a military power "of the first rank" and discharge certain international-social responsibilities to sustain international order (Bull 1977:201). Indeed, discharging such responsibility requires substantial military capability. McCourt's "residual Great Power" framing accepts this insight, arguing simply that - given its "residual" position, and its U.S./French alliances - the force levels required for the UK to meet this threshold are not particularly high.

The presumed tension between roleplay and realpolitik in approaches to greatness might, therefore, be seen as a straw-man. If the capability to independently defend one's own survival is part of what it means to be militarily "first rank", then it may also be part of what it means to be a "Great Power". This might render "residual" Great Power a nonsensical sub-category, if it suggests a "first-rank power" that is simultaneously not first-rank. But it would not necessarily 
mean that role-based and realist conceptions of greatness differ. After all, in Bull's conception (1977:213-19), a great power should be capable of unilaterally exercising a local preponderance of power - a position that explicitly excludes second-tier powers, Britain included (1977:203). This rebuttal to the "residual Great Power" thesis chimes with the structural-realist view that there have only been two powers great enough to qualify as "poles" in the international system since 1945 - and only one since $1989 .{ }^{26}$

More broadly, on Holsti's original framing (1970:262-63), remaining an "active independent" - necessitating sovereign military capability - is itself a role, not an alternative to role. "Great Power" can also incorporate many of Holsti's other roles - "regional protector", "defender of the faith", "balancer", and so forth - which similarly privilege military wherewithal. Christer Jönnson and Ulf Westerlund (1982) even identify "protector-of-own-state" as a role, treating realists' survival assumption as itself a role behavior. And in identifying the tensions between "great power" (giving the U.S. scope to act alone) and "hegemon" (which rewards multilateral leadership), Bruce Cronin (2001) treats both as roles, despite the former owing to material wherewithal (unilateral leeway) and the latter (diplomatic leadership) to social choice. Many varieties of realist thought admit a place for role concerns, moreover (Waltz 1993): the possibility of "greedy" states willing to fight for reasons beyond survival may explain security competition resulting from uncertainty over others' intentions, for example (Schweller 1996).

The attempted incorporation of the realist conception of "great power" into the role-based conception - the attempted elision of roleplay with relative power - is theoretically unsatisfactory, however, for four reasons. First, defining great powers as those discharging responsibilities towards international society and possessing substantial material power sets a behavioral threshold on "greatness" that amounts to Anglo-American status-quo bias. If World War II was not a "great power war", because Germany and Japan did not behave as "great" powers "should" - Bull's approach - then what conflicts between powerful states can the

\footnotetext{
26 "Residual pole" would obviously be nonsensical.
} 
definition hope to cover? Second, the order-upholding approach simultaneously sets a low bar on capability. Bull's "regional preponderance" criterion is wholly dependent on the relative strength of other regional actors: Australia can better exercise regional preponderance in Australasia than Germany or Russia ever could in Europe, but is not the greatest of the three. Consequently, Monteiro's criterion (2014:43-45) - sufficient capability to avoid certain defeat by the system's most powerful state - is integral to any survival-focused definition. Yet it is not necessarily integral to a definition premised on an order-upholding role. Third, assuming that survivaldefense is "automatically" embedded in the requirement to be a "first-rank" military power does not specify the relative capability threshold vis-à-vis other states required to defend specific interests. Even during Cold War bipolarity, the U.S. and USSR were very different sorts of “first-rank" military power, capability-wise (Ross 2009:50). Role-performance may thus require one military toolkit - enough expeditionary capability to uphold regional order - while survivaldefense may require another. Fourth, and most fundamentally, the elision is self-contradictory. Having an objective capability threshold means a state could falsely be perceived by others as "great"; role-performance would thus not in itself constitute greatness. Conversely, if intersubjective recognition of international-social role performance does constitute greatness, then there cannot also be external criteria to meet before a state can be considered "great", provided that its fellows regard it as such. ${ }^{27}$

As Holsti recognized (1970:298), role does not explain everything. "Defender-of-self" cannot simply be treated as an element of role if role theory is to retain explanatory power. For if merely continuing to exist is defined as role-performance, then role theory's valuable insights such as why states behave in ways not simply governed by desire for continued existence - risk being subsumed into unfalsifiable, post hoc labeling of all possible foreign-policy behaviors. Roleplay and realpolitik are thus complementary but non-identical. ${ }^{28}$ Conceding that the two are

\footnotetext{
${ }^{27}$ Capability may facilitate such recognition, obviously.

${ }^{28}$ For an exemplar of pulling together realist and constructivist insights to explain a key foreign-policy outcome, see Hemmer and Katzenstein (2002).
} 
separate incentive structures, capable of pulling states in different directions, paves the way for empirical study of this tension. And while the logical coherence of "neoclassical realism" has recently faced critique (Narizny 2017), the interaction of these two incentive structures adds a valuable strand to neoclassical realists' investigatory focus: the filtration of internationalsystemic pressures through domestic-political lenses (e.g. Kitchen 2010). ${ }^{29}$ A British case-study thus illuminates both UK strategy and core theoretical fault-lines in FPA/IR.

\section{How Do Roleplay and Realpolitik Coexist? The Empirical Interaction}

Empirically investigating the interplay of role-performance and realpolitik in UK foreign/defense policy presents two opposite challenges. First, pursuing strategic autonomy via independent military capability may itself be a primarily role-/status-motivated behavior (Holsti 1970:262-63; Volgy et al. 2011:6) - so the pursuit of military independence does not necessarily prove realpolitik's pre-eminence over roleplay. Second, strategic subordination to a close ally may itself reflect a survival-motivated calculation of external balancing requirements (Walt 1985) so close alignment with a greater power's global interventionism does not necessarily prove roleplay's pre-eminence over realpolitik either. Indeed, "residual power" role-performance still requires non-trivial capabilities to perform expeditionary, order-upholding military operations. But it nonetheless produces a different capability threshold: retaining independent means to assure survival sets a higher bar on readiness and availability than imposing order on others at a time of one's alliance's own choosing.

These challenges are surmountable, however, through granular analysis of strategic posture: parsing specific force levels, configurations, and readiness thresholds to discern UK international priorities. Crucially, this provides insights into opportunity costs - areas where Britain forgoes other public spending to acquire military capabilities. Assuming government

\footnotetext{
${ }^{29}$ E.g. if social role and material power shape states' behavior over varying time horizons, this would fit with the latest efforts to construct a cohesive neoclassical realist theory that systematizes the interaction of domestic and international politics (Ripsman, Taliaferro, and Lobell 2016:83-88).
} 
would rather procure election-winning welfare services and economic growth than military forces, any military spending is instructive. But acquisition of additional military capability, beyond the threshold for meaningful role/status gains - or where only marginal gains in greatpower roleplaying ability are attained, at the expense of hospitals, schools, or other kinds of military wherewithal - may indicate realpolitik logic at work. Conversely, elements of UK force posture being exposed as dependent on U.S./French burden-sharing provides evidence of prioritizing "residual" role-performance over the additional costs of generating independent capability. And when the UK bears the costs of independent national capability, but premised on habitual assumptions of allied support, the tensions between roleplay and realpolitik understandings of "greatness" in contemporary UK foreign/defense policy are fully exposed.

Part of the UK calculus likely owes to the pursuit of "strategic latency": another variety of hedging, premised around retaining sufficient capability in slow-to-regenerate domains that a larger force could be swiftly reconstituted if the security environment deteriorated (Cornish and Dorman 2012; 2015). Such an insight is consistent with the argument here: Britain still cares about the independent capability to safeguard its security, rather than solely discharging a "residual" role while trusting to allies. Regeneration lead-times alone do not account for the roleplay/realpolitik tensions identified below, however, since they do not vary consistently over the capabilities that have been reduced/removed versus those that have been retained/expanded hence the need for additional explanation.

Three brief cases, drawn from the periods of Britain's 2010 and 2015 NSS/SDSRs, show - contra McCourt - a Britain striving to be more than just a "residual" power discharging an international-societal role. There is also enduring impetus to retain independent capabilities for self-protection: to remain a major power against "realist" criteria. ${ }^{30}$ That said, the assumptions underpinning the deployment of those capabilities are themselves premised implicitly on alliance

\footnotetext{
${ }^{30}$ An impetus sharpened by major-power competition's resurgence since NSS/SDSR 2010 (Blagden 2009, 2015).
} 
support, insofar as they rest on the habit of a U.S.-dominated international order supplying secure global "commons". This belies a UK strategic posture conflicted between two purposes.

Ultimately, the point of these empirical cases is not to assess the overall severity of threat to Britain, or to determine whether defense is appropriately funded - although observers of UK policy could find grounds for critique. The point, rather, is to discern what British capability choices reveal about the state's own prioritization within the pool of resources allocated to national security. As the analysis demonstrates, Britain's own contemporary force-posture choices show (a) resurgent concern over hostile major-power threats, and (b) an enduring hedge against U.S. over-reliance/abandonment. Not all such choices can be explained as simply being useful subordinate allies in American global strategy, moreover - the charge that Britain's U.S.supporting expeditionary order-upholding is also survival-motivated bandwagoning, implying a permanent UK roleplay/realpolitik alignment - because the evidence shows otherwise. Even in a state so closely allied to the United States as Britain, there are good reasons - as discussed above - not to trust wholly to another's external balancing commitment, at least where there is the economic wherewithal to do otherwise. And sure enough, while Washington prizes interoperable subordinate forces from allies, all three cases illustrate Britain foregoing such U.S.-subordinated capabilities - another measure of opportunity cost - in pursuit of independent capabilities, some directly contrary to American preferences.

\section{The UK Nuclear Arsenal}

Since 1968, the UK has possessed a secure second-strike retaliatory nuclear capability, based on Continuous At-Sea Deterrence (CASD) sustained by a four-boat fleet of ballistic missilecarrying nuclear-powered submarines (SSBNs). ${ }^{31}$ Nuclear possession has been crucial to great-

\footnotetext{
${ }^{31}$ Initially the Polaris-carrying Resolution-class SSBNs (1960s-90s), followed by the Trident-carrying Vanguardclass SSBNs (1990s-present), to be replaced under the Dreadnought-class Successor Program from the late 2020s (HMG 2015:35-36; BBC 2016b). Britain's first air-droppable atomic weapons obviously preceded (1952).
} 
power role-performance since 1945 (McCourt 2014b:172), moreover, and role/status concerns have always informed British nuclear policy (Freedman 2003:295-96; Stocker 2007:34).

The question, however, is whether four-boat CASD represents the bare minimum consistent with "residual power" role-performance, or whether other considerations drive UK posture. McCourt contends that Britain could afford to descend the nuclear capability ladder via part-time SSBN patrols, say (2014b:172) - without jeopardizing its role. The UK could even abandon SSBNs altogether, retaining just a handful of air-deliverable bombs (for example), without relinquishing the status of "nuclear power".

Post-Cold War policy decisions have reinforced the bipartisan consensus on four-boat CASD, however. ${ }^{32}$ Both after and before the post-Crimea re-escalation of NATO-Russia tensions, successive Labour-/Conservative-led reviews of UK nuclear posture found CASD using four SSBNs the only prudent option (HMG 2006, 2010b:37-39, 2013, 2015:6). With 2016's decision to press ahead with a like-for-like replacement SSBN fleet, Britain is set to sustain this status quo into the 2060s (BBC 2016a).

Yet existing UK nuclear posture is costly. Sustaining CASD with no tolerance for interruptions requires at least four SSBNs (Chalmers 2014:7). The likely lifetime cost of the four-boat Successor SSBN Program is $>£ 200 b n$ in 2016 prices (BBC 2016a). It also requires two crews per boat - hence an outsized training/personnel establishment - along with extensive shore-basing infrastructure, other supporting naval forces, and so forth. Relaxing CASD towards a non-continuous posture would therefore deliver a significant fiscal "windfall" with negligible change in foreign/domestic publics' perceptions of Britain's global role, for whom UK nuclear possession may be significant but subtle variations in posture are not. ${ }^{33}$ Significant opportunity costs are thus being incurred to support four-boat CASD, a decision not explicable through meaningful role/status gains.

\footnotetext{
${ }^{32}$ A Jeremy Corbyn premiership could overturn such consensus, of course (Mason 2017).

${ }^{33}$ Surveys show a majority of Britons favor retaining nuclear weapons as long as others have them, but also favor a cheaper posture if one can be found safely (YouGov 2013:1-6).
} 
Realpolitik explains this cost-tolerance - specifically, enduring British ideas over the requirements of minimum deterrence (Stocker 2007:55-57). ${ }^{34}$ A non-continuous SSBN-based arsenal, or one reliant on air-/ground-/sea-launched cruise missiles would not provide assured retaliation - the non-deployed SSBN, or air/missile bases, would be vulnerable to preventive strike. And while UK nuclear possession has always been status-infused, the rationale for a credible deterrent is that it provides the ultimate means of independently safeguarding Britain's security against even the most capable adversaries (HMG 2006, 2013), hence London's longmaintained "Moscow Criterion" (Stoddart 2008). It is thus the final hedge against U.S. alliance abandonment, while buttressing NATO's overall credibility by providing a non-American center of nuclear decision (Stocker 2007:31).

Britain's nuclear posture therefore represents the strongest single piece of evidence that the country is not solely motivated by "residual power" role-performance concerns. UK policymakers are willing to incur substantial opportunity costs, above-and-beyond any meaningful role/status gains, to retain the ultimate independent self-safeguard of national survival and remain a major power on "realist" - as well as role-based - grounds. Those opportunity costs include expeditionary conventional forces, useful for role-performance, highlighting the tension. CASD is not simply a prop to U.S. hegemony, either; it is also the strongest single piece of evidence that British realpolitik is not observationally identical to American-subordinated roleplay. For the choice between $>£ 200 \mathrm{bn}$ of deployable, U.S.interoperable conventional forces versus a "useless" (except for deterrence) independent British nuclear arsenal would represent a "no-brainer", if the sole purpose of UK defense was to be "useful" to Washington. Instead, additional UK conventional capabilities (useful to America) are foregone - an opportunity cost - to procure the ultimate independent deterrent against majorpower threats (and hedge against U.S. abandonment).

\footnotetext{
34 The point is not whether this calculation of "minimum" deterrence requirements is "correct", but that it is the earnestly held motivation.
} 
There is a twist in this headline conclusion, however. Even while financing the ultimate means of self-protection, Britain has also accepted key elements of U.S. operational dependence. Some oft-cited dependencies are overstated: using the U.S.-made Trident D5 missile enables UK CASD for a fraction of what France pays for similar capability, ${ }^{35}$ and if Washington withdrew infrastructural support, Britain could offset the difference before its arsenal lost credibility (Chalmers and Chalmers 2013:6-7). Yet others are more telling. NSS/SDSR 2010 scrapped Britain's maritime patrol aircraft (MPAs) on cost grounds (HMG 2010b:27). MPAs are important for ensuring that submarines are not detected and trailed out of port, so their withdrawal constituted acceptance of major risk within UK nuclear posture (BBC 2011). This is consistent with McCourt's (2014b) appraisal of a "residual" power playing an alliance-enabled role. Based on the habit (Hopf 2010) of operating within a U.S.-dominated post-1990 international order that has provided Western command of the maritime "commons" (Posen 2003), the 2010-15 British government assumed that UK SSBNs would not face meaningful threats from hostile major powers independent of American protection, even while taking the costly decisions (HMG 2013) to replace a nuclear arsenal intended for just such a scenario! Following politically-embarrassing hostile submarine intrusions (Farmer 2014c, 2015; Merrill 2015), and in the post-Crimea context, NSS/SDSR 2015 redressed this MPA shortfall (HMG 2015:32). Still, operational intelligence affecting the credibility of UK nuclear posture could have been lost during the interim (Farmer 2015) - so 2010's risk-taking carried long-term possibilities.

The "MPA gap" episode is thus instructive. On the one hand, CASD sustainment and its costs show Britain acting to independently self-safeguard its survival. On the other hand, certain unconscious assumptions about U.S.-led hegemonic order - and Britain's consumption of alliance-supplied club goods within it - continued to condition even the highest domain of UK strategy, consistent with mere "residual" role-performance.

\footnotetext{
${ }^{35}$ France's nuclear arsenal has reportedly accounted for $\sim 20 \%$ of defense spending in the SSBN era, compared to Britain's 3\% (Jack 2016).
} 


\section{Royal Naval Fleet Composition}

The post-Cold War era has seen dramatic cuts to the Royal Navy (Hirst 2015). A force that quickly mustered 115 ships for the Falklands operation in 1982 possessed only 89 commissioned vessels by 2016, of which only a fraction were high-capability combatants (Axe 2016). Yet Britain has retained expansive global maritime security commitments since 1990 (Royal Navy 2012), leaning ever-more-heavily on NATO allies to sustain such "residual power" activism.

In line with "residual" role, McCourt (2014b:173) thus saw scope for Britain's replacement aircraft carrier program to be reduced to just one vessel, as Paris has done. ${ }^{36}$ This would ensure an alliance-enabled Anglo-French contribution to upholding international order, while permitting fiscal consolidation. Carriers are symbols of national status (Ross 2009:60), and important tools of overseas order-imposition, so even "residual" great powers prefer not to forego them altogether (McCourt 2014b:173). Accordingly, government ministers heralded the first new carrier's introduction as auguring a "bigger global role" for Britain (The Telegraph 2017). But as France's one-carrier posture illustrates (McCourt 2014b:173), a single ship is enough to generate such role-performative fanfare (Vonow and Charlton 2016).

Britain has remained committed to a two-carrier posture, however; the post-Crimea reemphasis on major war-fighting capabilities supplanting earlier talk (Webb 2009) of selling/mothballing one hull (HMG 2015:30). NSS/SDSR 2015 similarly recommitted to a full 138-aircraft through-program F-35 purchase, ensuring full-sized carrier air groups (HMG 2015:31). Given the opportunity costs of the carrier program - projected to total $£ 12.3 \mathrm{bn}$ (including aircraft) by the first vessel's entry into service (National Audit Office 2017:4) -

\footnotetext{
${ }^{36}$ Two Queen Elizabeth-class carriers, each capable of operating 50 aircraft, begin entering UK service from 2017. The last of three Invincible-class vessels, their smaller predecessors, was decommissioned in 2014.
} 
purchasing a second ship in the absence of meaningful extra role/status gains requires an alternative explanation: and realpolitik provides one. ${ }^{37}$

Debate continues over the contemporary strategic value of aircraft carriers (Hendrix 2015; Cropsey and McGrath 2015), but London has concluded that - if operating carriers at all it needs the permanent operational availability of a two-ship force (Dominiczak 2014). Roleassociated order-upholding foreign interventions can be timed to suit the intervener and/or coordinated with allies, but security-essential national naval tasks cannot. And again, this pursuit of independent capability cannot be elided as simply pursuing survival through U.S.-supporting roleplay. For in pursuing the affordability necessary for two-carrier permanent availability, the vessels were designed without catapult-launching/arrested-recovery capability, rendering them incompatible with most U.S. fixed-wing naval aircraft.

Again, however, there is a twist. Since the 1998 Strategic Defence Review, which promised two large carriers as replacements for the outgoing smaller three (HMG 1998:5), the Royal Navy's frigate, destroyer, and hunter-killer submarine (SSN) fleets have been near-halved, from 35 to nineteen frigates/destroyers and from twelve to seven SSNs (Hirst 2015). ${ }^{38}$ Thus, even while financing independent carrier air power to avoid alliance dependence, the forces necessary to protect carriers - and perform tasks in places where the carriers are not - have been hollowed-out (Axe 2016). The consequence is a force stretched beyond its assured operational limits by the size of the policy it serves (Merrill 2016; House of Commons Defence Committee 2016; Sharman 2017).

Again, internalized assumptions about U.S.-supplied hegemonic order explain the disconnect. As NSS/SDSR 2015 argues, "the world continues to look to [America] to shape

\footnotetext{
${ }^{37}$ Roleplay/realpolitik is not the exhaustive universe of variables here: bureaucratic politics and domestic-political economy likely also contributed to the original two-carrier choice. Nonetheless, there are alternative ways to create bureaucratic prestige or support industry/jobs, besides building - and then retaining/operating - two carriers: so the permanent-availability rationale remains central, as stated explicitly by policymakers (Dominiczak 2014).

${ }^{38}$ Like any navy, only a fraction - around a third - of these are deployable at any one time, given training/maintenance/leave/upgrades. Day-to-day availability is reportedly often lower still, given older vessels' wear-and-tear and newer designs’ immaturity (Merrill 2016; Sharman 2017).
} 
global stability", even while also promising to retain "the UK's ability to undertake war-fighting independently" (HMG 2015:51). Thus, even in striving for independent major-power naval capabilities, the post-1990 habit of U.S. unipolarity leads London to assume that it will never actually operate them on anything other than a Western-dominated maritime "commons".

\section{RAF Fast Jets and UK/NATO Air Defense}

The counterinsurgency-centric 2010 NSS/SDSR was coy on combat aircraft numbers, promising only that Britain would operate the modern FGR4 Typhoon and F-35 Lightning while withdrawing the aging GR9 Harrier and GR4 Tornado (HMG 2010b:25-27). This, along with a plan to withdraw early-model Typhoons while scaling-back planned F-35 purchases, yielded a Royal Air Force (RAF) fast jet fleet of only seven combat-capable squadrons by 2014 (Farmer 2014a), with an expectation of further decrease (Gilligan 2010; BBC 2015b).

Such drawdown came despite a backdrop of sustained high-tempo air operations. Consistent with a "residual great power" role, these included bombing campaigns alongside French and/or U.S. forces over Libya (Bingham 2011), Afghanistan (Farmer 2014b), and Iraq/Syria (Norton-Taylor 2015a). Yet beyond such order-upholding discretionary interventions, and in line with the deterioration of NATO-Russia relations, they also included numerous Quick Reaction Alert (QRA) sorties against Russian approaches to UK airspace (Johnston 2014) and significant contributions to NATO theater air defense (BBC 2015a).

Accordingly, going beyond "tokenistic" contributions to bolster home and regional air defense against a hostile major power, NSS/SDSR 2015 committed to significant re-growth of RAF combat jet numbers (HMG 2015:31), totaling three additional squadrons. Alongside recommitment to a full 138-aircraft through-program F-35 purchase, the Typhoon fleet will be grown, by retaining the earlier Tranche 1 aircraft as Tranche 3 enters service (Osborne 2016). ${ }^{39}$ With the retained Typhoons as dedicated QRA squadrons (FighterWeek 2016), the aim is to

${ }^{39}$ Britain has ordered 160 Typhoons (Tovey 2015), of which 138 had been delivered by November 2016 (Airbus 2016). 
increase sovereign self-protection capability against a hostile major power. Again, this shows Britain focusing on an imperative other than role. London is incurring opportunity costs to generate a $>200$-aircraft combat jet fleet, much of it earmarked only for safeguarding national airspace against high-capability state aggressors, thereby conforming to "realist" survival imperatives. And again, this cannot be dismissed as simply being useful to America: enhanced domestic air defense, with little utility in expeditionary operations (because of Tranche 1's limited ground-attack capability), would not be Washington's first-choice use of additional airpower resources in a major ally.

Again, however, there is a twist. RAF fast jet operations have been consolidated to only three home air bases, for financial efficiency (HMG 2010b:33). ${ }^{40}$ Anti-missile defenses around those bases - and around critical command-and-control (C2) infrastructure - are also reportedly non-existent (DefenceSynergia 2016; Jones 2016). U.S. planners devote considerable attention to countering their crucial bases' vulnerability and scarcity (Stillion and Orletsky 1999; Heginbotham et al. 2015). Yet British RAF stations critical to national/NATO defense have been left vulnerable, on cost grounds, to disablement via a few hangar/runway/C2 cruise-missile strikes, even while resources have been poured into aircraft intended for just such a contingency - large-scale attack by a strike-capable adversary (Jones 2016). More generally, with stocks of munitions, spares, fuel, and specialist expertise at unprecedentedly low levels (Jones 2016), premised on "just-in-time" resupply from global markets, the RAF's ability to wage a sustained air defense campaign is limited, ${ }^{41}$ despite expenditure on aircraft.

What might explain such risk-acceptance, even while consciously recommitting to national air defense? As a just-retired Joint Forces Commander scathingly informed Britain's Defence Secretary (Jones 2016), the habit of U.S.-provided air command and resupply has produced a British posture premised on "international" (i.e. American) support. Again, therefore, Britain is consciously striving to retain independent capability to safeguard its own survival,

\footnotetext{
${ }^{40}$ RAFs Lossiemouth, Coningsby, and Marham; U.S. Air Force F-15s also operate from RAF Lakenheath.
}

${ }^{41}$ A complaint that also reportedly holds for maritime and land forces. 
consistent with realpolitik. But again, its posture retains "residual power" assumptions about alliance-supplied club goods, in the form of U.S.-enforced hegemonic stability.

\section{Conclusion}

Performing an international-societal role and safeguarding state survival are not the same thing: even when prescribed policies coincide, they remain analytically distinct incentive structures. And while a country that does not survive cannot achieve anything else either, states' role concerns and survival requirements are not always aligned. Differing conceptions of "Great Power" illustrate this tension. Whereas a role-based conception may incentivize military activism abroad to uphold international order, realist criteria prioritize the independent means to defend one's own hierarchy of security interests. These two conceptions cannot be readily elided in theory, moreover, for "greatness" cannot simultaneously be based on inter-subjective social role recognition and an objective threshold of national power. Of course, in practice, both material and ideational power exist on a spectrum that shape states' foreign/defense policies, as both constructivist and realist perspectives recognize. Nonetheless, isolating roleplay and realpolitik as separate incentive structures sheds light on the ways in which different logics of international behavior pull states' policies in different directions.

Contemporary Britain displays these tensions in stark relief. The UK remains obsessed with performing an elevated international-societal role as an alliance-enabled upholder of a particular notion of international order, consistent with the "residual" great power thesis. ${ }^{42}$ But Britain also still strives for a continuing ability to perform perceivedly survival-essential military missions, independent of potentially unreliable allies' charity: to be a "real" major power, on realist criteria. And yet, even in consciously striving for this enduring nucleus of sovereign selfprotection capability, the post-1990 habit of operating within a U.S. unipolar system reflects itself in embedded assumptions about alliance-supplied Western dominance.

\footnotetext{
${ }^{42}$ See footnotes 3 and 2 , respectively.
} 
British strategy is thus shaped by the interaction between two conflicting conceptions of "greatness": one willing to bear significant realpolitik-motivated opportunity costs to preserve independent self-protection capability, the other premised on a supporting role in upholding U.S.-led international order. ${ }^{43}$ Abandonment by the superpower patron is consciously hedged against, yet the habit of operating under Pax Americana conditions that very hedging. Britain is thus both a "real" and a "residual" power at the same time. Brexit-induced economic vulnerabilities may yet jeopardize the UK force commitments analyzed, of course (Blagden 2017:11-12) - and a future Corbyn-led, anti-nuclear Labour government could change UK posture dramatically (Mason 2017) - but that they were made remains telling.

The article confirms that role concerns are a significant explanatory variable in states' foreign policy choices. Beyond Britain lie likely parallels, particularly in similarly statusobsessed second-tier powers, like France and Russia. On the other hand, the imperative to survive as a state - and the different military-strategic thresholds this may create - provides an explanatory boundary on foreign-policy role theory, since role conceptions and survival requirements can conflict. This provides a promising avenue of future inquiry, particularly for those - "neoclassical" realist or otherwise (Kitchen 2010; Narizny 2017) - seeking additional perspectives on the interplay between states' domestic preferences and international-structural pressures.

\section{References $^{44}$}

AIRBus.(2016) Orders, Deliveries, In Operation Military Aircraft by Country - Worldwide. 30 November. https://airbusdefenceandspace.com/wp-content/uploads/2016/12/201611_mrs_gen_ord-deliv-by-country.pdf.

Art, RobERT J.(1980) To What Ends Military Power? International Security 4(4):3-35. AXE, DAVID.(2016) What the U.S. should learn from Britain's dying navy. Reuters, 11 August. http://uk.reuters.com/article/us-uk-military-navy-commentaryidUKKCN10L1AD.

\footnotetext{
${ }^{43}$ NSS/SDSR 2015 listed Britain’s National Security Objectives as “protect our people”, "project our global influence", and "promote our prosperity" (HMG 2015:11-12), encapsulating this motivational tension between realpolitik/survival (people-protection) and roleplay/status (influence-projection) perfectly.

${ }^{44}$ All cited URLs accessible as of 11 April 2018.
} 
BARBER, JAMES.(1980) Britain's Place in the World. British Journal of International Studies 6(2):93-110.

BBC.(2011) Scrapping RAF Nimrods 'perverse' say military chiefs. 27 January. http://www.bbc.co.uk/news/uk-england-12294766.

-.(2015) UK to lead 'high readiness' NATO force, Michael Fallon says. 5 February. http://www.bbc.co.uk/news/uk-31147236.

-.(2015) RAF fighter plane numbers to reach 'all-time low'. 22 July. http://www.bbc.co.uk/news/uk-33618484.

-.(2016) A guide to Trident and the debate about its replacement. 18 July. http://www.bbc.co.uk/news/uk-politics-13442735.

-.(2016) New nuclear submarine given famous naval name. 21 October. http://www.bbc.co.uk/news/uk-37720580.

Bew, John.(2015) Realpolitik: A History. Oxford: Oxford University Press.

BInGHAM, JoHn.(2011) Libya: RAF makes history with epic bombing raid. The Telegraph, 21 March. http://www.telegraph.co.uk/news/worldnews/africaandindianocean/libya/8394018 /Libya-RAF-makes-history-with-epic-bombing-raid.html.

Blagden, DAVID.(2009) Strategic Thinking for the Age of Austerity. RUSI Journal 154(6):6066.

-.(2015) Global Multipolarity, European Security and Implications for UK Grand Strategy: Back to the Future, Once Again. International Affairs 91(2):333-350.

-.(2017) Britain and the World after Brexit. International Politics 54(1):1-25.

BlAIR, DAVID.(2016) How Britain can build a new role for itself in the world. The Telegraph, 25 June. http://www.telegraph.co.uk/opinion/2016/06/25/how-britain-can-build-a-new-rolefor-itself-in-the-world/.

BlaIR, TONY.(1999) Doctrine of the International Community. UK Prime Minister's Speech to the Economic Club of Chicago, 24 April. http://webarchive.nationalarchives.gov.uk/+/www.number10.gov.uk/Page1297.

BREUnING, MARIJKE.(1995) Words and Deeds: Foreign Assistance Rhetoric and Policy Behavior in the Netherlands, Belgium, and the United Kingdom. International Studies Quarterly 39(2):235-254.

Brinkley, Douglas.(1990) Dean Acheson and the 'Special Relationship': The West Point Speech of December 1962. Historical Journal 33(3):599-601.

Brummer, Klaus, AND CAMERON G. ThiEs.(2014) The Contested Selection of National Role Conceptions. Foreign Policy Analysis 11(3):273-293.

Bull, Hedley.(1977) The Anarchical Society: A Study of Order in International Relations. New York: Columbia University Press.

Cantir, Cristian, And Juliet KaArbo.(2012) Contested Roles and Domestic Politics: Reflections on Role Theory in Foreign Policy Analysis and IR Theory. Foreign Policy Analysis 8(1):5-24.

Chalmers, Hugh.(2014) A Disturbance in the Force: Debating Continuous At-Sea Deterrence. London: Royal United Services Institute.

Chalmers, Hugh, And Malcolm Chalmers.(2013) The Future of the UK's Cooperative Nuclear Relationships. London: Royal United Services Institute.

Clark, IAN.(1989) The Hierarchy of States: Reform and Resistance in the International Order. Cambridge: Cambridge University Press.

- (2005) Legitimacy in International Society. Oxford: Oxford University Press. 
-. (2009) Towards an English School Theory of Hegemony. European Journal of International Relations 15(2):203-228.

Clarke, Michael.(2010) Has the Defence Review secured Britain's place in the world? Commentary (Royal United Services Institute), 20

October. https://rusi.org/commentary/has-defence-review-secured-britains-place-world.

CoOK, RoBIN.(1997) Robin Cook's speech on the government's ethical foreign policy. The Guardian, 12

May. https://www.theguardian.com/world/1997/may/12/indonesia.ethicalforeignpolicy.

Copeland, Dale C.(2000) The Constructivist Challenge to Structural Realism: A Review Essay. International Security 25(2):187-212.

-.(2003) A Realist Critique of the English School. Review of International Studies 29(3):427441.

Cornish, Paul, AND ANDrew M. Dorman.(2012) Smart Muddling Through: Rethinking UK National Strategy beyond Afghanistan. International Affairs 88(2):213-22.

-.(2015) Complex Security and Strategic Latency: The UK Strategic Defence and Security Review 2015. International Affairs 91(2):351-70.

CRONIN, BRUCE.(2001) The Paradox of Hegemony: America's Ambiguous Relationship with the United Nations. European Journal of International Relations 7(1):103-130.

Cropsey, Seth, AND BRyAn MCGrath.(2015) America's defense still requires aircraft carriers. National Review, 23

April. http://www.nationalreview.com/article/417339/americas-defense-still-requiresaircraft-carriers-seth-cropsey-bryan-mcgrath.

Crowcroft, Robert, AND Owen A. HARTLEy.(2012) 'Mind the Gap': Divergent Visions of National Priorities and the International System within Contemporary British Government. Defence Studies 12(4):479-502.

DAVID, MAXINE.(2015) State of the Nation: Britain's role in the world just keeps shrinking. The Conversation, 17 April. https://theconversation.com/state-of-the-nation-britains-role-inthe-world-just-keeps-shrinking-39276.

DEFENCESYNERGIA.CO.UK.(2016) UK air defence - a forgotten capability gap. 4 February. http://www.defencesynergia.co.uk/uk-air-defence-a-forgotten-capability-gap/.

DOMINICZAK, PETER.(2013) Tory leaders insist Britain still has role to play on world stage. The Telegraph, 30 August. http://www.telegraph.co.uk/news/politics/10277726/Tory-leadersinsist-Britain-still-has-role-to-play-on-world-stage.html.

-.(2014) Britain will have second aircraft carrier. The Telegraph, 5 September. http://www.telegraph.co.uk/news/uknews/defence/11078244/Britain-willhave-a-second-aircraft-carrier.html.

DunNe, Tim.(2004) 'When the Shooting Starts': Atlanticism in British Security Strategy. International Affairs 80(5):893-909.

FARMER, BEN.(2014) 'Bare bones' RAF will struggle to mount Iraq operation. The Telegraph, 25 September. http://www.telegraph.co.uk/news/uknews/defence/11121465/Bare-bonesRAF-will-struggle-to-mount-Iraq-operation.html.

-.(2014) RAF Tornados leave Afghanistan for last time. The Telegraph, 11 November. http://www.telegraph.co.uk/news/uknews/defence/11223852/RAF-Tornadosleave-Afghanistan-for-last-time.html.

-.(2014) Britain forced to ask NATO to track 'Russian submarine' in Scottish waters. The Telegraph, 9 
December. http://www.telegraph.co.uk/news/uknews/defence/11283926/Britain-forcedto-ask-Nato-to-track-Russian-submarine-in-Scottish-waters.html.

-.(2015) Nimrod cuts 'have allowed Russian submarines to spy on Trident'. The Telegraph, 29 May. http://www.telegraph.co.uk/news/uknews/defence/11639510/Nimrod-cuts-haveallowed-Russian-submarines-to-spy-on-Trident.html.

Fearon, James D.(2011) Two States, Two Types, Two Actions. Security Studies 20(3):431-440. FighterWEEK.COM.(2016) Tranche 1 Typhoons to be UK Alert Force. 20 April. https://fightersweep.com/4988/tranche-1-typhoons-uk-alert-force/.

FINANCIAL TIMES.(2016) Britain ponders its role in the world beyond Europe. 15 July. https://www.ft.com/content/06cae42a-4a7f-11e6-b387-64ab0a67014c.

FreEdMAn, LAWRENCE.(2003) The Evolution of Nuclear Strategy. Basingstoke: Palgrave Macmillan ( $3^{\text {rd }}$ ed.).

FRY, ROBERT.(2015) Defence review: what is Britain's place in the world? Prospect Magazine, 24 November. http://www.prospectmagazine.co.uk/politics/defence-review-what-isbritains-place-in-the-world.

GASKARTH, JAMIE.(2006) Discourses and Ethics: The Social Construction of British Foreign Policy. Foreign Policy Analysis 2(4):325-341.

-.(2014) Strategizing Britain's Role in the World. International Affairs 90(3):559-581.

GEYeR, MichaEL.(1986) German Strategy in the Age of Machine Warfare, 1914-1945. In Peter Paret (ed.), Makers of Modern Strategy from Machiavelli to the Nuclear Age. Princeton: Princeton University Press. 527-597.

GiLes, Chris, AND KATIE MARTIN.(2017) Theresa May vows Britain will not withdraw from global role after Brexit. Financial Times, 19 January. https://www.ft.com/content/9415b692-de23-11e6-9d7c-be108f1c1dce.

GILLIGAN, ANDREW.(2010) RAF commander: our air force will be little better than Belgium's. The Telegraph, 18 December. http://www.telegraph.co.uk/news/uknews/defence/8212090/RAFcommander-our-air-force-will-be-little-better-than-Belgiums.html.

GiLmore, JonAthan.(2014) The Uncertain Merger of Values and Interests in UK Foreign Policy. International Affairs 90(3):541-557.

Glaser, Charles L.(2010) Rational Theory of International Politics: The Logic of Competition and Cooperation. Princeton: Princeton University Press.

Goddard, Stacie E., And Daniel H. Nexon.(2016) The Dynamics of Global Power Politics: A Framework for Analysis. Journal of Global Security Studies 1(1):4-18.

GÜRZEL, AYLIN.(2014) Turkey's Role as a Regional and Global Player and Its Power Capacity: Turkey’s Engagement with Other Emerging States. Revista de Sociologia e Politica 22(50):95-105.

Heginbotham, ERic, et Al.(2015) Chinese Attacks on Air Bases in Asia: An Assessment of Relative Capabilities, 1996-2017. Santa Monica: RAND.

Helm, ToBy.(2013) Poll finds 60\% of British public oppose military action against Syria. The Guardian, 31 August. https://www.theguardian.com/politics/2013/aug/31/poll-britishmilitary-action-syria.

Hemmer, Christopher, And Peter J. Katzenstein.(2002) Why is there no NATO in Asia? Collective Identity, Regionalism, and the Origins of Multilateralism. International Organization 56(3):575-607. 
HENDRIX, JERRY.(2015) The U.S. Navy needs to radically reassess how it projects power. National Review, 23 April. http://www.nationalreview.com/article/417306/ageaircraft-carrier-over-jerry-hendrix.

Hicks, KATHLEEN.(2015) America's changing role in the world. Huffington Post, 16 November. http://www.huffingtonpost.com/kathleen-hicks/americas-changing-role-inthe-world_b_8560324.html.

HIRST, TOMAS.(2015) There has been a dramatic decline in the size and capability of the UK's armed forces. Business Insider, 20 February. http://uk.businessinsider.com/the-declineof-the-uk-armed-forces-in-charts-2015-2.

Hill, Christopher.(1979) Britain's Elusive Role in World Politics. British Journal of International Studies 5(3):248-259.

-.(2016) Powers of a Kind: The Anomalous Position of France and the United Kingdom in World Politics. International Affairs 92(2):393-414.

HM Government.(1998) Strategic Defence Review: Modern Forces for the Modern World. Norwich: HM Stationery Office.

-.(2006) The Future of the United Kingdom's Nuclear Deterrent. Norwich: HM Stationery Office.

-.(2010) A Strong Britain in an Age of Uncertainty: The National Security Strategy. Norwich: HM Stationery Office.

-.(2010) Securing Britain in an Age of Uncertainty: The Strategic Defence and Security Review. Norwich: HM Stationery Office.

-.(2013) Trident Alternatives Review. London: Cabinet Office.

-.(2015) National Security Strategy and Strategic Defence and Security Review 2015: A Secure and Prosperous United Kingdom. Norwich: HM Stationery Office.

Holsti, KaleVi J.(1970) National Role Conceptions in the Study of Foreign Policy. International Studies Quarterly 14(3):233-309

Hopf, TED.(1998) The Promise of Constructivism in International Relations Theory. International Security 23(1):171-200.

-.(2010) The Logic of Habit in International Relations. European Journal of International Relations 16(4):539-561.

House of Commons Defence CommitTee.(2016) Restoring the Fleet: Naval Procurement and the National Shipbuilding Strategy: Third Report of Session 2016-17. London: Parliament.

Humphreys, AdAm R. C.(2011) The Heuristic Application of Explanatory Theories in International Relations. European Journal of International Relations 17(2):257-277.

-.(2015) From National Interest to Global Reform: Patterns of Reasoning in British Foreign Policy Discourse. British Journal of Politics and International Relations 17(4):568-584.

HuRD, IAN.(1999) Legitimacy and Authority in International Politics. International Organization 53(2):379-408.

JACK, IAN.(2016) Trident: the British question. The Guardian, 11 February. https://www.theguardian.com/uk-news/2016/feb/11/trident-the-britishquestion.

Jenkin, Bernard, And George Grant.(2011) The Tipping Point: British National Strategy and the UK's Future World Role. London: Henry Jackson Society. 
JOHnston, CHRIs.(2014) RAF intercepts Russian bomber approaching UK airspace. The Guardian, 1 November. https://www.theguardian.com/uk-news/2014/nov/01/raf-russianbomber-uk-airspace.

JONES, EvAN.(2017) "Sellout" Ministries and Jingoes: China's Bureaucratic Institutions and the Evolution of Contested National Role Conceptions in the South China Sea. Foreign Policy Analysis 13(2):361-379.

JONES, SAM.(2016) Britain's 'withered' forces not fit to repel all-out attack. Financial Times, 16 September. https://www.ft.com/content/36f47240-7c0e-11e6-ae24-f193b105145e.

JÖnNson, Christer, AND Ulf Westerlund.(1982) Role Theory and Foreign Policy Analysis. In Cognitive Dynamics and International Politics, edited by Christer Jönsson. London: Pinter. 122-157.

Kitchen, Nicholas.(2010) Systemic Pressures and Domestic Ideas: A Neoclassical Realist Model of Grand Strategy Formation. Review of International Studies 36(1):117-143.

KlotZ, AudiE.(1995) Norms Reconstituting Interests: Global Racial Equality and U.S. Sanctions against South Africa. International Organization 49(3):451-478.

Krauthammer, Charles.(1990-91) The Unipolar Moment. Foreign Affairs 70(1): 23-33.

LAKE, DAVID A.(1996) Anarchy, Hierarchy, and the Variety of International Relations. International Organization 50(1):1-33.

-.(2011) Hierarchy in International Relations. Ithaca: Cornell University Press.

LANDALE, JAMES.(2016) G20: Questions for Theresa May over UK's global role. BBC, 2 September. http://www.bbc.co.uk/news/uk-politics-37246633.

LARSOn, Deborah Welch, AND ANDREI SheVChENKo.(2010) Status Seekers: Chinese and Russian Responses to U.S. Primacy. International Security 34(4):63-95.

Lebow, Richard Ned.(2010) Why Nations Fight: Past and Future Motives for War. Cambridge: Cambridge University Press.

MacLeod, Alex.(1997) Great Britain: Still Searching for Status? In Role Quests in the PostCold War Era: Foreign Policies in Transition, edited by Philippe G. Le Prestre. Montreal and Kingston: McGill-Queen's University Press. 161-186.

Maslow, Abraham H.(1943) A Theory of Human Motivation. Psychological Review 50(4):370-396.

MASON, RowENA.(2017) Corbyn refuses to back Trident but says he will respect Labour position. The Guardian, 26

May. https://www.theguardian.com/politics/2017/may/26/jeremy-corbyn-trident-labourmanifesto-commitment.

Maull, Hanns W.(1990) Germany and Japan: The New Civilian Powers. Foreign Affairs 69(5):91-106.

McCourT, DAvid M.(2011) Rethinking Britain's Role in the World for a New Decade: The Limits of Discursive Therapy and the Promise of Field Theory. British Journal of Politics and International Relations 13(2):145-164.

-.(2011) Role-playing and Identity Affirmation in International Politics: Britain's Reinvasion of the Falklands, 1982. Review of International Studies 37(2):1599-1621.

-.(2014) Britain and World Power since 1945: Constructing a Nation's Role in International Politics. Ann Arbor: University of Michigan Press.

-.(2014) Has Britain Found its Role? Survival 56(2):157-178.

Mearsheimer, John J. (2001) The Tragedy of Great Power Politics. New York: Norton.

-.(2009) Reckless States and Realism. International Relations 23(2):241-256. 
MERRILL, JAMIE.(2015) MoD asks for American help in searching for Russian submarine near Scotland. The Independent, 8

January. http://www.independent.co.uk/news/uk/politics/mod-asks-for-american-help-insearching-for-russian-submarine-near-scotland-9966080.html.

-.(2016) Falkland Islands left with no Royal Navy warship protection for first time since 1982 conflict. The Independent, 1 April. http://www.independent.co.uk/news/uk/homenews/falklands-islands-left-with-no-royal-navy-warship-protection-for-first-time-since1982-conflict-a6964491.html.

MitZen, JenNifER.(2006) Ontological Security in World Politics: State Identity and the Security Dilemma. European Journal of International Relations 12(3):341-70.

MonteIro, Nuno P.(2014) Theory of Unipolar Politics. Cambridge: Cambridge University Press.

Morgenthau, Hans J.(1973) Politics Among Nations: The Struggle for Power and Peace. New York: $\operatorname{Knopf}\left(5^{\text {th }}\right.$ ed. $)$.

MORRIS, JUSTIN.(2011) How Great is Britain? Power, Responsibility and Britain's Future Global Role. British Journal of Politics and International Relations 13(3):326-247.

NARIZnY, KeVIn.(2017) On Systemic Paradigms and Domestic Politics: A Critique of the Newest Realism. International Security 42(2):155-90.

National Audit Office.(2017) Delivering Carrier Strike: Summary. London: UK National Audit Office.

Neves, Aécio, And Ashley Collins.(2015) Politics and Progress: Senator Neves Analyzes Brazil's Role in the World. Harvard International Review 37(1). http://hir.harvard.edu/politics-and-progress-senator-neves-analyzes-brazils-role-inthe-world/.

NEW STATESMAN.(2015) Britain's role in the world. 5

February. http://www.newstatesman.com/politics/2015/02/leader-britains-role-world.

Niblett, Robin.(2010) Playing to its Strengths: Rethinking the UK's Role in a Changing World. London: Chatham House.

NORTON-TAYLOR, RICHARD.(2015) Scale of UK attacks on Islamic State in Iraq revealed. The Guardian, 11 May. https://www.theguardian.com/world/2015/may/11/uk-attacks-islamicstate-iraq-revealed-drones.

-.(2015) Britain's global role at stake as security review takes shape. The Guardian, 3 November. https://www.theguardian.com/news/defence-and-securityblog/2015/nov/03/britains-global-role-at-stake-as-security-review-takes-shape.

NOUGAYRĖDE, NATALIE.(2016) Britain will still be unable to define its global role without Europe. The Guardian, 11

July. https://www.theguardian.com/commentisfree/2016/jul/11/britain-unable-defineglobal-role-europe-brexit.

OsBORNE, TONY.(2016) UK Tranche 1 Typhoon revamping gets others interested in model. Aviation Week, 22 November. http://aviationweek.com/combat-aircraft/uktranche-1-typhoon-revamping-gets-others-interested-model.

Paul, T. V., Deborah Welch Larson, And William C. Wohlforth (eds.).(2014) Status in World Politics. Cambridge: Cambridge University Press.

PORTER, HENRY.(2013) What budget for defence? First let's work out Britain's place in the world. The Observer, 3 
February. http://www.theguardian.com/commentisfree/2013/feb/03/british-defencespending-needs-addressing.

PorTer, PATRICK.(2010) Why Britain Doesn't Do Grand Strategy. RUSI Journal 155(4):6-12.

Posen, BARry R.(2003) Command of the Commons: The Military Foundation of U.S. Hegemony. International Security 28(1):5-46.

Price, Richard, AND NinA TANNENWALD.(1996) Norms and Deterrence: The Nuclear and Chemical Weapons Taboos. In The Culture of National Security: Norms and Identity in World Politics, edited by Peter J. Katzenstein. New York: Columbia University Press. 114-152.

Ripsman, Norrin M., JefFrey W. TAliaferro, And Steven E. Lobell.(2016) Neoclassical Realist Theory of International Politics. Oxford: Oxford University Press.

RoBBINS, JAMES.(2015) Is the UK still sure of its role on the world stage? $B B C, 10$ March. http://www.bbc.co.uk/news/uk-31797298.

Ross, RoBert S.(2009) China's Naval Nationalism: Sources, Prospects, and the U.S. Response. International Security 34(2):46-81.

Royal Navy.(2012) The Royal Navy, Fact Sheet 1: Deployed Forward-Operating Globally. Portsmouth: RN Fleet Graphics Centre.

Schweller, RANDALl L.(1996) Neorealism's Status-quo Bias: What Security Dilemma? Security Studies 5(3):90-121.

SHARMAN, JON.(2017) Royal Navy's entire fleet of attack submarines out of action. The Independent, 10 February.http://www.independent.co.uk/news/uk/politics/royal-navysubmarine-fleet-world-class-claims-out-of-action-order-maintenance-attack-substrafalgar-a7572746.html.

Shlaim, AVI.(1975) Britain's Quest for a World Role. International Relations 5(1):838-856.

Sil, Rudra, And Peter J. Katzenstein.(2010) Analytic Eclecticism in the Study of World Politics: Reconfiguring Problems and Mechanisms across Research Traditions. Perspectives on Politics 8(2):411-431.

Singham, SHANKER.(2016) Great Britain's role in the world. CapX, 26 April. https://capx.co/great-britains-role-in-the-world/.

STEINMEIER, FrANK-WALTER.(2016) Germany’s New Global Role. Foreign Affairs 95(4):106113.

Stevenson, Alex.(2011) Britain's diminished place in the world. Politics.co.uk, 9 March. http://www.politics.co.uk/comment-analysis/2011/03/09/comment-britain-sdiminished-place-in-the-wor.

Stillion, John, AND DAVID T. ORLETSKy.(1999) Airbase Vulnerability to Conventional CruiseMissile and Ballistic-Missile Attacks: Technology, Scenarios, and U.S. Air Force Responses. Santa Monica: RAND.

StODDART, KRISTAN.(2008) Maintaining the 'Moscow Criterion': British Strategic Nuclear Targeting, 1974-1979. Journal of Strategic Studies 31(6):897-924.

StOCKer, Jeremy.(2007) The United Kingdom and Nuclear Deterrence. Abingdon: Routledge/IISS.

Strachan, Hew.(2009) The Strategic Gap in British Defence Policy. Survival 51(4):49-70.

THAYER, BRADlEy A.(2000) Bringing in Darwin: Evolutionary Theory, Realism, and International Politics. International Security 25(2):124-151. 
THE ECONOMIST.(2015) Muscle memory: Britain's role in the world. 12

February. http://www.economist.com/news/britain/21643137-britains-strategic-ambitionhas-shrivelled-even-more-its-defence-budget-muscle-memory.

THE GUARDIAN.(2010) The UK's world role: Great Britain's greatness fixation. 25 January. https://www.theguardian.com/commentisfree/2010/jan/25/britain-world-roleeurope-us.

THE TELEGRAPH.(2017) HMS Queen Elizabeth is 'clear signal' of UK's 'global power', Theresa May says as ship arrives in Portsmouth. 16 August. http://www.telegraph.co.uk/news/2017/08/16/hms-queen-elizabetharrivesportsmouth-crowds-greet-new-warship/.

ThIES, CAMERon G.(2017) Role Theory and Foreign Policy [2010]. In The International Studies Encyclopedia, edited by Robert A. Denemark and Renée Marlin-Bennett. New York: Wiley-Blackwell/ISA. eISBN:9780191842665; DOI:10.1093/acref/9780191842665.001.0001.

Thies, CAmeron G., AND MariJKe Breuning.(2012) Integrating Foreign Policy Analysis and International Relations through Role Theory. Foreign Policy Analysis 8(1):1-4.

TILly, Charles.(1992) Coercion, Capital, and European States, AD 990-1992. Oxford: Blackwell.

TOVEY, AlAn.(2015) BAE slashes cost of making Typhoon jet fighters as it seeks export orders. The Telegraph, 19

July. http://www.telegraph.co.uk/finance/newsbysector/industry/defence/11749347/BAEslashes-cost-of-making-Typhoon-jet-fighters-as-it-seeks-new-export-orders.html.

TURnER, Michael J.(2010) Britain's International Role, 1970-2010. Basingstoke: Palgrave Macmillan.

Volgy, Thomas J., Renato Corbetta, Keith A. Grant, And Ryan G. Baird (eds.).(2011) Major Powers and the Quest for Status in International Politics: Global and Regional Perspectives. New York: Macmillan.

Vonow, BritTANy, AND COREY CHARLTON.(2016) France to deploy its biggest warship to take on ISIS. The Sun, 15 July. https://www.thesun.co.uk/news/1448428/french-presidentholds-emergency-meeting-as-death-toll-from-nice-attack-continues-to-mount/.

Walker, Stephen G.(1987) Role Theory and Foreign Policy Analysis (ed.). Durham: Duke University Press.

WALt, StePhEn M.(1985) Alliance Formation and the Balance of World Power. International Security 9(4):3-43.

Waltz, Kenneth N.(1967) Foreign Policy and Democratic Politics. Boston: Little, Brown.

-.(1979) Theory of International Politics. New York: Random House.

-.(1993) The Emerging Structure of International Politics. International Security 18(2): 44-79.

WeBB, Tim.(2009) Royal Navy aircraft carrier may be sold to India. The Guardian, 19 November. https://www.theguardian.com/business/2009/nov/16/royal-navy-aircraftcarrier-sale.

Wendt, AleXAnder.(1999) Social Theory of International Politics. Cambridge: Cambridge University Press.

Wivel, ANDERs.(2008) Balancing against Threats or Bandwagoning with Power? Europe and the Transatlantic Relationship after the Cold War. Cambridge Review of International Affairs 21(3):289-305. 
WOHLFORTH, WiLliam C.(1999) The Stability of a Unipolar World. International Security 24(1):5-41.

YouGov.(2013) YouGov Survey Results. 23-24

April. http://cdn.yougov.com/cumulus_uploads/document/dq60jrxc27/YG-ArchivePublic-Administration-Select-Committee-results-240413-Trident-nuclearweapons.pdf\#page $=7$. 